\title{
WIELOKULTUROWOŚĆ EUROPY ŚRODKOWO-WSCHODNIEJ. \\ KILKA METODOLOGICZNYCH UWAG O DEFINIOWANIU I BADANIU ZJAWISKA
}

$\mathrm{O}$ becność wielokulturowości w dyskursie zarówno publicznym, jak i naukowym świadczy bez wątpienia o wadze tego zjawiska we współczesnej rzeczywistości, ale również wskazuje na charakteryzujące je odmienności - dotyczą one zwłaszcza stanowisk, które decydują o różnorodności podejść do samego sposobu definiowania wielokulturowości, jak i licznych jego egzemplifikacji. Brak spójności w tej materii wiązać należy przynajmniej z trzema aspektami. Pierwszy z nich dotyczy poszukiwania podmiotu wielokulturowości - czy są to wyłącznie grupy etniczne i narodowościowe, które z historyczno-genetycznego punktu widzenia stanowiły jedyny punkt odniesienia i kształtowały ramy dyskusji o wielokulturowości, czy też należy doń dołączyć inne grupy/mniejszości kulturo$w^{1}$. Drugi ze wspomnianych aspektów odnieść należy do obszarów, w kontekście których mówić możemy o istnieniu wielokulturowości oraz - w konsekwencji - do zastosowanych teorii służących ich analizie i charakterystyce. W tym momencie uwidaczniają się rozbieżności w kwestii środkowo-wschodnioeuropejskich "pokładów wielokulturowości” w opozycji do tych charakteryzujących kraje zachodnioeuropejskie oraz te, w których zrodziła się ideologia wielokulturowości. Ważny przy tym pozostaje sposób implementowania teorii wypracowanej(ych) w tych krajach do analizy złożoności kulturowej społeczeństw Europy Środkowo-Wschodniej. Trzecia, ostatnia z wymienianych, przyczyna niespójności wiąże się z terminologią i dotyczy

1 W.J. Burszta, Ideologia różnicy i tożsamość zbiorowa, „Sprawy Narodowościowe" 1999, z. 14-15, s. 53.

Dr Kamilla DOLIŃSKA jest adiunktem w Zakładzie Socjologii Pogranicza Uniwersytetu Wrocławskiego. dolinskakamilla@gmail.com

Dr Julita MAKARO jest adiunktem w Zakładzie Socjologii Pogranicza Uniwersytetu Wrocławskiego. jmakaro@wns.uni.wroc.pl 
dwóch pojęć: „wielokulturowości” (w różnych jej kontekstach) oraz pojawiającego się obok lub zamiennie pojęcia "multikulturalizm”.

Prezentowane refleksje stanowić mają zatem próbę dookreślenia wielokulturowości jako złożonego zjawiska społeczno-kulturowego w środkowo-wschodnioeuropejskim kontekście, którego podmiotem są wszelkie grupy etniczne (w szerokim tego słowa znaczeniu) zamieszkujące terytorium Europy Środkowo-Wschodniej. Za Jerzym Bańskim przyjmujemy, że obszar ten wiązać należy głównie z państwami posocjalistycznymi, powstałymi w wyniku rozpadu większych tworów państwowych.

„Do Europy Środkowo-Wschodniej należą prócz Polski, Czech, Słowacji i Węgier, państwa nadbałtyckie (Litwa, Łotwa, Estonia), państwa dawnej Jugosławii (Serbia, Chorwacja, Stowenia, Macedonia, Czarnogóra, Bośnia i Hercegowina) oraz Rumunia, Bułgaria i Albania. Historycznie do Europy Środkowo-Wschodniej należą też zachodnie części Białorusi i Ukrainy"².

Przyjęte przez nas założenia teoretyczne, prezentujące odmienne (choć nie rozłączne) poziomy wielokulturowości, konsekwentnie łączyć będziemy z propozycjami metodologicznymi, w obrębie których przedstawione zostaną pewne wytyczne uwzględniające specyfikę danego poziomu: określony przedmiot badań/analiz, jak i sposób pozyskiwania danych empirycznych zarówno o charakterze ilościowym jak i jakościowym. Szerokie spektrum egzemplifikacji empirycznych (jeśli chodzi o rodzaj pozyskiwanych danych) w badaniu wyodrębnionych poziomów wielokulturowości wynika z faktu różnic uwidaczniających się na poziomie teoretycznego opisu zjawisk i procesów zachodzących w poszczególnych jej wymiarach oraz odmiennego ich współtworzenia i doświadczania przez poszczególnych uczestników wielokulturowej rzeczywistości. Tego typu decyzja to konsekwencja podzielenia przekonań Andrzeja Piotrowskiego, który pisał:

„założenia o tym, czym jest rzeczywistość społeczna, wyznaczają wybór metody jej badania w tym sensie, że skłaniają do eliminacji procedur nie chwytających zjawisk istotnych na gruncie określonych teorii. I odwrotnie, wybór metody, owocujący określonym zbiorem danych i sposobów ich opracowania, przesądza w dużej mierze o zakresie zjawisk, o których badacz będzie mógł orzekać"3.

\section{POZIOM „REALNEGO ZRÓŻNICOWANIA”}

Wielokulturowość na pierwszym z wyróżnionych poziomów jest dającym się empirycznie potwierdzić i zmierzyć zjawiskiem demograficznym, ujmowanym w kategoriach opisowych: wielość kultur jako nie tylko „panorama świata podzielonego na oddzielne geograficznie kultury etniczne”, ale również „rzeczywistość nasycenia poszczególnych państw

2 J. Bański, Polska i Europa Środkowo-Wschodnia w koncepcjach podziału Europy, w: Problematyka geopolityczna ziem polskich, red. P. Eberhardt, Prace Geograficzne, 218, IGiPZ PAN, Warszawa 2008, s. 121-134. Złożoność zjawiska wielokulturowości w Europie Srodkowo-Wschodniej wzmacnia dodatkowo fakt różnic pomiędzy poszczególnymi krajami. Dotyczą one "1) okresu, w którym ukształtowały się poszczególne narody; 2) faktu posiadania (bądź nie) własnego państwa w różnych okresach historycznych; 3) doświadczeń politycznych zgromadzonych w przeszłości, jeśli chodzi o systemy polityczne własnych państw bądź państw, na terenie których się znalazły; 4) stopniem etnicznej (narodowej) homogeniczności w przeszłości i obecnie; 5) przeszłymi i obecnymi doświadczeniami w stosunkach międzyetnicznych (...)". R. Siemieńska, Narody Wschodniej i Środkowej Europy o sobie i innych, w: Trudne sąsiedztwa. Z socjologii konfliktów narodowościowych, red. A. Jasińska-Kania, Wydawnictwo Naukowe SCHOLAR, Warszawa 2001, s. 48.

3 A. Piotrowski, Teoria a badania empiryczne. Pare uwag o ich związku w orientacjach współczesnej socjologii, w: Teoria i praktyka socjologii empirycznej, red. A. Giza-Poleszczuk, E. Mokrzycki, IFiS PAN, Warszawa 1990, s. 21. 
i społeczeństw zróżnicowanymi populacjami odwołującymi się przy określaniu tożsamości grupowej do argumentu "własnej kultury", traktowanej jako autonomiczna całość"4. Określanie własnej tożsamości poprzez odwołanie się do faktu bycia członkiem konkretnej grupy jest szczególnie widoczne i istotne socjologicznie w sytuacji, gdy istnieją określone kategorie pojęciowe pozwalające hipostazować wyróżnione grupy etniczne czy religijne (będące grupami społecznymi w sensie socjologicznym, charakteryzującymi się wyraźną ciągłością międzypokoleniową) $)^{5}$.

Badanie wyodrębnionego przez nas poziomu wielokulturowości jako "realnego zróżnicowania" powinno się skupić na empirycznej diagnozie zróżnicowania struktury społecznej, ze względu na wyodrębnione kryteria. Poszukiwania badawcze powinny zmierzać do opisania między innymi następujących kwestii:

1) bezwzględnej liczby ludności należącej do kategorii etnicznych innych niż grupa dominująca,

2) liczby kategorii etnicznych innych niż grupa dominująca,

3) ich udziału w całej populacji (co pozwoli określić zakres zjawiska zróżnicowania i pozycję grupy dominującej),

4) rozmieszczenia w przestrzeni kraju (co z kolei pozwoli określić obszary monokulturowe oraz te, gdzie mniejszości etniczne stanowią większość liczebną),

5) zakresu stosowania różnych języków ojczystych w przestrzeni prywatnej,

6) stopnia zróżnicowania religijnego.

Sformułowane powyżej zadania realizowane mogą być przy wykorzystaniu dokumentów urzędowych i analizie innych danych wtórnych. W przypadku tak zakreślonego pola badawczego badacz jest bardzo ograniczony dostępnością danych wytwarzanych przez różne instytucje, które pozyskują informacje zazwyczaj z zupełnie pozanaukowych inspiracji. Pytania zadawane w spisach powszechnych nie zawsze odpowiadają potrzebom bada$\mathrm{czy}^{6}$, niektóre - jak pytanie o religijność - w ogóle nie są zadawane. Statystyki Kościołów różnych wyznań prowadzone są według odmiennych metodologii, a dostęp do nich bywa utrudniony. Nie istnieją również gotowe spisy instytucji działających na rzecz mniejszości, a ich częste regionalne rozproszenie potęguje problem tworzenia wyczerpujących baz danych - na przykład szkół, w których prowadzone jest nauczanie w języku mniejszości lub stowarzyszeń mniejszościowych. W rozpoznaniu zjawiska wielokulturowości jako „realnego zróżnicowania" pewnych całości społecznych odwołać się można również do ustaleń innych badaczy - socjologów i antropologów - pracujących na danych wywoływanych. Wszak przez dekady w Polsce nie rejestrowano innych niż polska narodowości, a mimo wszystko naukowcy szacowali wielkości poszczególnych mniejszości narodowych i etnicznych w oparciu o ustalenia poczynione właśnie w trakcie badań terenowych. Z drugiej strony, prowadząc badania porównawcze i korzystając z wcześniejszych ustaleń empirycznych, nie powinno się zapominać, w jakich warunkach różne dyscypliny naukowe funkcjonowały w krajach Europy Środkowo-Wschodniej w czasach komunizmu - idzie

4 W.J. Burszta, op. cit., s. 52.

J. Mucha, Oblicza etniczności, Zakład Wydawniczy NOMOS, Kraków 2005, s. 52, 57.

6 Przykładowo - Andrzej Sadowski podkreśla, że w ramach współczesnych badań nad zróżnicowaniem narodowo-etnicznym społeczeństw przestaje być przydatne założenie o rozłącznej przynależności etnicznej, co wynika z narastającego zjawiska podwójnej lub częściowej przynależności narodowej. Dlatego też pytania spisowe powinny być formułowane w taki sposób, aby odzwierciedlały „rzeczywiste autoidentyfikacje narodowościowe" - wszelka standaryzacja pytań i odpowiedzi wytwarza sytuacje zmuszającą respondenta do wybrania określonej opcji tożsamościowej. Autor podkreśla istotność sposobu sformułowania pytania oraz interpretacji odpowiedzi. Zob. szerzej: A. Sadowski, Narodowościowe i etniczne zróżnicowanie III RP, w: Jedna Polska. Dawne i nowe zróżnicowania społeczne, red. A. Kojder, Wydawnictwo WAM PAN, Kraków 2007, s. 540-543. 


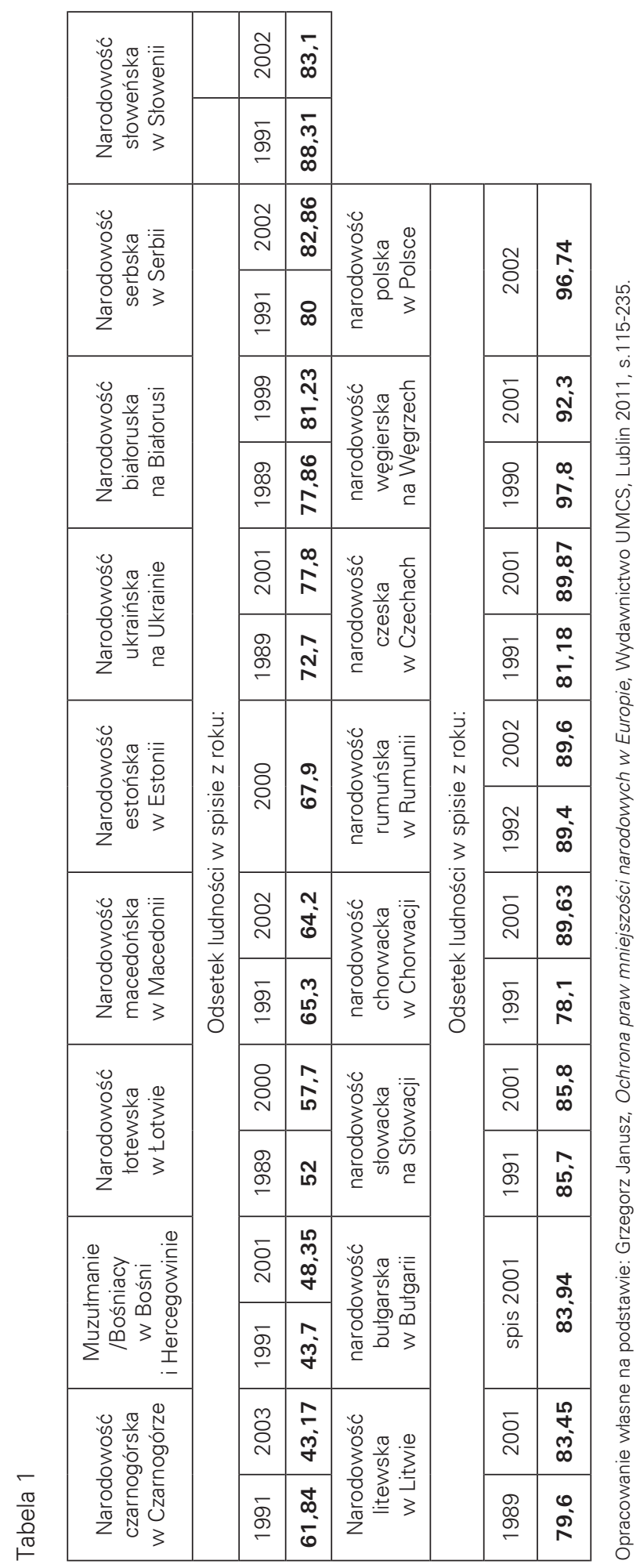


tu z jednej strony o dominujące (narzucone) paradygmaty teoretyczne, z drugiej o kwestie organizacyjne i służebność badaczy względem władzy?

Korzystanie z danych zastanych ma w naszym przekonaniu dwie fundamentalne konsekwencje. Pierwszą można zinterpretować jako niekorzystną - jest mianowicie badacz skazany na istniejące już dane, których temat oraz poziom agregacji nie musi mu odpowiadać z punktu widzenia stawianych pytań badawczych. Drugiej można przypisać waloryzację pozytywną, jeśli zwróci się uwagę na fakt, iż dokumenty urzędowe dostarczają czasami takich danych, do których zebrania niezbędne jest zaplecze organizacyjne, a takowymi dysponują właśnie duże instytucje, szczególnie powołane do gromadzenia danych (GUS). Ich zebranie przez badacza, z powodów technicznych i finansowych, nie byłoby możliwe ${ }^{8}$

Badanie wielokulturowości wyrażającej się „realnym zróżnicowaniem” w krajach Europy Środkowo-Wschodniej, ze względu na różne możliwości i zwyczaje w gromadzeniu danych na temat narodowości, używania języka ojczystego oraz wyznania musi uwzględniać specyfiki regionalne, a nawet krajowe. Sytuację komplikuje jeszcze kwestia czasu i historii przeobrażeń geopolitycznych z dwiema wyraźnymi cezurami czasowymi w historii najnowszej: II wojną światową i upadkiem państw wielonarodowych w latach 90. XX wieku. Można powiedzieć, że ów proces różnicowania odmiennie wyglądał w dwóch fazach: fazie jałtańsko-poczdamskiej, charakteryzującej się usankcjonowaniem masowych przesiedleń oraz fazie postradzieckiej, cechującej się rozpadem państw wielonarodowych i odrodzeniem życia narodowego i religijnego'.

Niosące najdalsze konsekwencje zmiany zaszły po rozpadzie ZSRR i Jugosławii, w mniejszym stopniu Czechosłowacji. Generalnie można rzec, że odrodzenie życia narodowego i religijnego było głównie korelatem nowych warunków ustrojowych oraz dotyczyło całego obszaru Europy Środkowo-Wschodniej. Wszystkie te zjawiska wpływają na stan realnego zróżnicowania kulturowego w krajach postkomunistycznych. Również względne otwarcie granic zintensyfikowało zjawisko „nowych migracji”, które przyczyniają się do modyfikowania dotychczasowego „empirycznego stanu rzeczy” (np. masowa emigracja z byłych republik radzieckich Żydów, imigracja Koreańczyków do Polski).

Ustalenie zakresu obecności mniejszości narodowych i etnicznych w poszczególnych krajach Europy Środkowo-Wschodniej jest w większości przypadków możliwe na podstawieo danych ze spisów powszechnych. W poniższej tabeli prezentowane są informacje pochodzące z dwóch ostatnich spisów powszechnych realizowanych w poszczególnych krajach. Należy wyraźnie zaznaczyć, że ich porównywalność jest ograniczona i opisują one często dwie różne sytuacje: w roku 1989 realizowany był spis w ZSRR (i te dane, liczone dla odpowiednich republik, są publikowane), natomiast w 1991 roku przeprowadzono spis ludności w Jugosławiii ${ }^{10}$. Najnowsze spisy realizowane były w niezależnych państwach.

7 Na ograniczoną przydatność wcześniejszych ustaleń w zakresie religijności zwraca uwagę I. Borowik, która przywołuje typologię postaw religijnych stosowaną w byłym Związku Radzieckim: „[...] ateiści, przekonani niewierzący, bezreligijni, wątpiący i tylko jedna kategoria wierzących - przekonani wierzacy"; I. Borowik, Odbudowywanie pamięci. Przemiany religijne w Środkowo-Wschodniej Europie po upadku komunizmu, Zakład Wydawniczy NOMOS, Kraków 2000, s. 170.

8 Pamiętać należy o wszelkich zastrzeżeniach, ale i korzyściach, jakie wobec dokumentów urzędowych, jako źródła w badaniach socjologicznych zgłaszał Antoni Sułek, Ogród metodologii socjologicznej, Wydawnictwo Naukowe SCHOLAR, Warszawa 2002, s. 103-147.

9 J. Lewandowski, Narody, religie, państwa, mniejszości, w: Mniejszości narodowe i religijne w Europie Środkowowschodniej, red. J. Kłoczowski, P. Kras, IEŚW, Lublin 1993, s. 29-32.

10 Korzystając $z$ danych spisowych dotyczących narodowości, pamiętać należy o ich obciążeniu, które roboczo można nazwać politycznym. W różnych przypadkach, zarówno rejestrującym jak i rejestrowanym, zależeć może na określonym efekcie. Manipulowanie danymi podczas spisów w ZSRR opisuje ks. Roman Dzwonkowski, Problem liczebności Polaków i katolików obrządku łacińskiego na Białorusi i Ukrainie, w: Mniejszości 
Dane zawarte w Tabeli 1 wskazują na wielkość grupy dominującej, podstawowego żywiołu narodowego, choć jak widać nie wszędzie stanowi on nawet połowę społeczeństwa. Powyższa informacja nie wskazuje co prawda na stopień z różnicowania sam y ch m niejs zości, ale na siłę ich obecności w państwie (w wielu krajach Europy Środkowo-Wschodniej występuje około 10 różnych kategorii o odmiennych identyfikacjach narodowych, w Bośni i Hercegowinie oraz Macedonii odpowiednio 6 i 7, w Rumunii 19, natomiast w Chorwacji aż 25. Z kolei w Białorusi rejestruje się 122 narodowości mniejszościowe, przy czym 100 z nich stanowi zaledwie 0,15\% populacji; w Ukrainie odnotowano 130 narodowości innych od większościowej, z czego ponad 110 z nich stanowi 0,4\% populacji). Inaczej będzie kształtować się wielokulturowość w społeczeństwie, w którym co drugi lub co trzeci mieszkaniec nie należy do grupy dominującej, inaczej, gdy będzie to cecha co dziesiątego czy co dwudziestego obywatela.

Dane spisowe często przynoszą informacje o uży waniu języka ojczyste g o. Jest to ważna kwestia dla badania wielokulturowości, a szczególnie interesujące wydaje się zestawianie informacji o narodowości z danymi o kompetencjach i praktykach językowych, świadczące o tym, jak odmiennie w specyficznych okolicznościach kształtują się określone determinanty tożsamości narodowych. Tego rodzaju zjawisko obrazują przykłady z wybranych krajów Europy Środkowo-Wschodniej. W Estonii więcej osób deklaruje przynależność do większościowej narodowości estońskiej oraz mniejszościowych narodowości: ukraińskiej, białoruskiej, fińskiej i łotewskiej niż posługiwanie się językiem tych narodowości; prawie 15\% przyjmujących ukraińską orientację narodową za język ojczysty uznaje rosyjski, przedstawiciele narodowości węgierskiej i krymsko-tatarskiej w ponad 90\% używają języka narodowego, a wśród ludności o polskiej identyfikacji narodowej używanie języka polskiego, jako narodowego, zadeklarowało zaledwie $13 \%$. Na Słowacji liczba osób deklarujących przynależność do narodowości mniejszościowych jest mniejsza niż liczba osób mówiących w określonych językach narodowych. Podobnie w Bułgarii odnotowano więcej deklaracji o posługiwaniu się językiem bułgarskim i tureckim niż o przynależności do tych kategorii narodowych; analogiczną jest sytuacja języka i narodowości chorwackiej. Z kolei w Słowenii za język ojczysty uznaje włoski, węgierski i romski więcej osób, niż deklaruje przynależność do tych grup narodowych ${ }^{11}$. Przeobrażenia w praktyce językowej - stanowiącej przecież jeden z istotnych czynników identyfikacji narodowych i etnicznych - widać również na przykładzie byłej Jugosławii. Jak przypomina Georg Auernheimer,

„Podczas gdy dziewiętnastowieczny nacjonalizm południowosłowiański podkreślał wspólnotę serbskiego i chorwackiego i zatroszczył się o ich syntezę, a serbochorwacki stał się potem podstawą językową nowego państwa - współcześnie jakby o tym zapomniano, a podręczniki do nauki języka i słowniki muszą zostać od nowa opracowane"12.

Istotną zmienną wpływającą na kształt zjawiska wielokulturowości jest przestrzenne rozmieszczenie kategorii niedominujących, wielokulturowe mogą

narodowe i religijne w Europie Środkowo-Wschodniej w świetle statystyk XIX i XX wieku, red. J. Skarbek, Z. Sułowski, IEŚW, Lublin 1995.

11 Ten typ pomiaru nie wyczerpuje oczywiście wszelkich kwestii zróżnicowania językowego. Nowe interesujące zjawisko ograniczania roli języka rosyjskiego na Litwie charakteryzuje Ludmiła Burenina. Wskazując na różne obszary funkcjonowania języka (komunikacja masowa, telewizja, radio, periodyki, zdobywanie wykształcenia, obszar pracy, dyplomacji, kultury, kontaktów międzyludzkich), pokazuje ona, w których z nich język przeżywa regres, a w których jest nadal funkcjonalny; por.: L. Burenina, Status języka rosyjskiego i ludności rosyjskiej na Litwie, w: O potrzebie dialogu kultur i ludzi, red. T. Pilch, Wyd. Żak, Warszawa 2000.

12 G. Auernheimer, Edukacja międzykulturowa w roli wychowania politycznego, w: O potrzebie dialogu kultur i ludzi, red. T. Pilch, Wyd. Żak, Warszawa 2000, s. 109. 
bowiem być całe społeczeństwa albo regiony, albo miasta i wsie. To szczególnie ważne, jeśli uświadomimy sobie, iż wiele omawianych społeczności traktowanych i opisywanych jest jako monokulturowe ${ }^{13}$. Z drugiej strony należy pamiętać i o tym, że

„W momencie rysującego się rozpadu Federacyjnej Republiki Jugosławii jedno było niewątpliwe: niemożność wykrojenia narodowościowo jednorodnych państw. Przemieszanie zwartych grup etnicznych w różnych terenach jest duże, że bardzo trudno wykroić państwa jednorodne etnicznie"14.

Takie czynniki charakterystyczne dla Europy Środkowo-Wschodniej, jak: zmiana lub stanowienie nowych granic państwowych, migracje (przymusowe i dobrowolne) czy konflikty etniczne powodują specyficzne rozmieszczenie i natężenie zróżnicowania kulturowego. W Estonii mniejszości narodowe zamieszkują częściej w miastach niż na wsiach, w Czarnogórze odsetek przedstawicieli mniejszości narodowych wśród mieszkańców miast był niższy od średniej krajowej, na Łotwie i na Wegrzech większość mniejszości narodowych zamieszkuje stolice kraju, a na Litwie większość mniejszości skupionych jest w obwodzie wileńskim. Na Półwyspie Krymskim narodowość ukraińska jest liczebnie w mniejszości - w tym przypadku historycznie ukształtowany porządek społeczny jest równie ważny jak najnowsze zjawiska, na przykład migracji:

„Zrozumiałą jest rzeczą, że zmiany społeczne są uwarunkowane zmianami warunków życia ludzi zamieszkujących regiony Ukrainy, tj. odrębnie ukształtowane obszary historyczne [...] Specyfikę tę określa, bynajmniej nie w ostatniej kolejności, skład etniczny mieszkańców każdego z regionów. Będąc systemem złożonym, różnorakim, do którego wchodzą różne narody (czy ich części) o odmiennych drogach rozwoju historycznego i tradycjach, specyfice mentalności narodowych i in. - ludność poszczególnych regionów buduje własne warunki życiowe"15.

Ciekawym obszarem badawczym jest zróżnicowanie religijne Europy Środkowo-Wschodniej (szczególnie w przyjętej przez nas szerokiej definicji obszaru, w którym historycznie zaznaczyły się wpływy co najmniej trzech wielkich religii). Pytanie o religijność umieszczone jest w spisie powszechnym przeprowadzanym w Bułgarii. W pozostałych przypadkach można positkować się dokumentami różnych Kościołów bądź wynikami badań terenowych ${ }^{16}$. Dlatego też charakterystyki dotyczące zróżnicowania religijnego bywają rozbieżne. W samej Europie Środkowo-Wschodniej znajdziemy kraje o strukturze mono- i multireligijnej, w poszczególnych zaś dominują różne wyznania, co pozwala analizować wielokulturowość części Europy jak i poszczególnych państw. Krzysztof Dybciak ${ }^{17}$ następująco charakteryzuje strukturę wyznaniową niektórych z nich: w Polsce około 93\% ludności to katolicy; na Wegrzech jest 64\% katolików, 23\% protestan-

13 Adekwatnym dla omawianej kwestii wydaje się opracowanie Blahoslava Krausa, Wspótistnienie wielokulturowe a mniejszości w Republice Czeskiej, w: O potrzebie dialogu kultur i ludzi, red. T. Pilch, Wyd. Żak, Warszawa 2000, s.181; autor wskazuje na monokulturowy charakter społeczeństwa czeskiego, argumentując niemal 95\% udziatem osób deklarujących narodowość czeską, morawską lub śląską (sic!), podawanych razem. Tymczasem Morawianie w spisie z 1991 roku stanowili około 13\%, a w 2001 prawie 4\%.

14 T. Mazowiecki, Jugostowiańska przestroga, w: Mniejszości narodowe i religijne w Europie ŚrodkowoWschodniej w świetle statystyk XIX i XX wieku, red. J. Kłoczowski, P. Kras, IESW, Lublin 1993, s. 36.

15 T. Rudnicka, Mniejszości narodowe na Ukrainie: status społeczny, problemy i perspektywy, w: O potrzebie dialogu kultur i ludzi, red. T. Pilch, Wyd. Żak, Warszawa 2000, s. 287.

16 Za niewystarczające uznać należy opieranie się wyłącznie na księgach metrykalnych Cerkwi czy Kościoła, dlatego powinny być one traktowane jako dopełnienie badań terenowych, por.: A. Mironowicz, Ksiegi metrykalne w badaniach demograficznych kościoła prawostawnego, w: Mniejszości narodowe i religijne w Europie Środkowo-Wschodniej w świetle statystyk XIX i XX wieku, red. J. Skarbek, Z. Sułowski, IESW, Lublin 1995.

17 Autor podaje dane z dwóch źródet: Nowej Encyklopedii Powszechnej PWN z 1996 roku oraz Leksykonu państw świata 94/95 wydanego w 1994 roku, opracowanego przez Harenberg Kommunikation Verlags und Mediengesellschaft w Dortmundzie: K. Dybciak, Co znaczy katolickość Europy Środkowej?, w: Europa Środkowa: wspólnota czy zbiorowość, red. R. Zenderowski, Wrocław 2004, s. 20-22. 
tów ${ }^{18}$; w Chorwacji około 77\% stanowią katolicy, a 11\% prawosławni; na Litwie szacuje się, że katolicy stanowią 60-80\%, pozostałe wyznania to prawosławni i protestanci (kalwini i luteranie); w Słowacji dominują katolicy, a w Słowenii stanowią oni około 90\%. Inne niż katolickie wyznania dominują w Estonii, gdzie większość to luteranie; w Czechach jest 30\% katolików, 8\% protestantów, 2\% prawosławnych; na Łotwie 55\% to luteranie, 24\% katolicy, 9\% prawosławni; w Rumunii około 70\% to prawosławni, 7\% protestanci, 10\% stanowią unici, a 2\% katolicy ${ }^{19}$. Pamiętać również należy o nowych związkach wyznaniowych, które jednak w ujęciu ilościowym są marginalne.

\section{POZIOM ŚWIADOMOŚCIOWY}

Drugi z wyróżnionych przez nas poziomów ukierunkowuje refleksję na wielokulturowość jako zjawisko doświadczane w ramach codzienności, którego zasadniczą treść stanowi świadomość obecności Innego w przestrzeni społecznej stanowiącej obszar jednostkowego i grupowego funkcjonowania społecznego. Wiązać ją należy, co podkreśla Janusz Mucha, z istnieniem niesformalizowanych, wielorakich norm społecznych, aprobujących i regulujących owo wspótistnienie. Ten rodzaj wielokulturowości pojawia się W sytuacji,

„gdy zarówno na poziomie lokalnym, jak i ogólnospołecznym ludzie uświadamiają sobie, że niektórzy ich sąsiedzi uznają inne niż oni sami wartości, przestrzegają innych norm, realizują inne praktyki kulturowe w życiu codziennym, i gdy ci ludzie uważają ten stan za normalny" 20.

Można zatem założyć, iż to właśnie wspólne doświadczanie określonej przestrzeni geograficznej i społecznej staje się podstawą wykreowania systemu aksjonormatywnego odpowiadającego codziennej praktyce, wynikającej nie tyle z przymusu, ile z wewnętrznej potrzeby. Marek Krajewski pisał, iż wielokulturowość jest

„ciągłą i indywidualną próbą przetłumaczenia przymusu wspótistnienia na jego potrzebę (...) jest potrzebą nawiązania rozmowy z sąsiadem mieszkającym w domu obok, ale różniącym się ode mnie wyznaniem, kolorem skóry; jest negocjowaniem z nim warunków naszego sąsiedztwa, godzeniem się co do najprostszych spraw. Wielokulturowość jest więc małym, lokalnym sojuszem" 21 .

Relacje międzyludzkie wpisane w ramy wielokulturowości na poziomie świadomościowym doskonale zatem wpisują się w problem relatywizmu ocen, jakie jednostki przypisują innym, a odniesienie tego problemu do refleksji zahaczającej o kontinuum „obcy - inny - swój" stanowić może szansę na dookreślenie pewnych warunków, których spełnienie, w świadomie doświadczanej przestrzeni wielokulturowej, stanie się podstawą zawarcia wspomnianego lokalnego sojuszu oraz przemiany "obcego" W „innego", a nawet "swojego". Przy czym ów poziom świadomościowy może być, w pewnych sytuacjach, niezależny od poziomu „realnego zróżnicowania” oraz ustaleń politycznych wpisanych w ramy wielokulturowości oficjalnej (o której piszemy w kolejnej części artykułu)

Na poziomie świadomościowym badać można zarówno samo dostrzeganie i postrzeganie zróżnicowania, jak i życie codzienne w zróżnicowanej rzeczywistości:

18 Nieco inne wielkości dla Węgier podaje Irena Borowik, op. cit., s. 97: katolicy 70\%, kalwini 19\%, luteranie $4 \%$.

19 K. Dybciak, op. cit., s. 20-22.

20 J. Mucha, op. cit., s. 52

21 M. Krajewski, Paradoksy wielokulturowości, w: Teorie społeczne a możliwości praktyczne, red. R. Cichocki, Wydawnictwo „Media-G.T.", Poznań 1997, s. 32. 
1) wyobrażenie i definiowanie Innego,

2) codzienne interakcje, regulujące je normy, wypracowywanie reguł współżycia spotecznego,

3) koszty i korzyści wynikające z wielokulturowości,

4) wartościowanie wielokulturowości jako atrakcyjnej/nieatrakcyjnej; pożądanej/niepożądanej, naturalnej/nienaturalnej.

Dotarcie do istoty tak rozumianego zjawiska możliwe jest z zastosowaniem badań ilościowych i jakościowych, przy czym większe możliwości poznawcze wiążą się z zastosowaniem odpowiednich procedur jakościowych. Dotarcie do złożonych, często nieuświadamianych przekonań badanych jest możliwe przy zastosowaniu takich metod, jak: wywiad swobodny, wywiad fokusowy, obserwacja uczestnicząca, studium przypadku czy badania biograficzne. Oczywiście każda z metod ma swoje ograniczenia i zalety, zarówno w możliwości stosowania jak i w potencjale interpretacyjnym. Łączy je wszak jedno - pozwalają dotrzeć do świadomości badanych. Procesualność zjawiska zróżnicowania kulturowego w Europie Środkowo-Wschodniej jest oczywista, jeśli spojrzymy na jej skomplikowane losy historyczne. Zmiana społeczna powoduje konieczność redefiniowania i ciągłego konstruowania codziennej rzeczywistości. Dlatego też pytania badawcze winny dotyczyć tego, jak badani doświadczają różnych elementów codzienności i jakie nadają im znaczenia. Celem dociekań badawczych w tej perspektywie jest zatem ustalenie, jak kształtuje się zjawisko wielokulturowości z perspektywy aktora społecznego ${ }^{22}$.

Państwa Europy Środkowo-Wschodniej można dla prowadzonych tu rozważań podzielić na dwa typy: te, które od czasów konferencji poczdamskiej pozostają w niemal niezmiennej formule narodowościowo-terytorialnej (np. Polska, Bułgaria, Wegry), oraz te, które swoje nowe ramy państwowe, terytorialne, narodowościowe ustalały (w pokojowy lub konfliktowy sposób) na nowo w latach 90. ubiegłego wieku (np. państwa powstałe po rozpadzie Związku Radzieckiego i Jugosławii). Wydawać by się mogło, że w krajach pierwszego typu proces ustanawiania relacji społecznych z mniejszościami narodowymi i religijnymi trwa już kilkadziesiąt lat, a obecność Innych w codziennym życiu jest rzeczą „naturalną". Jednak pamiętać trzeba o obowiązującej przez lata ideologii państw jednolitych narodowo, które nie pozwalały zanadto demonstrować swojej odrębności samym mniejszościom, co z kolei utrudniało ich „dostrzeganie” przez grupę dominującą. Dlatego też w Polsce odradzanie tożsamości narodowych i etnicznych wiążemy z początkiem lat 90. ubiegłego wieku (instytucjonalizacja działalności w stowarzyszeniach, przedstawiciele mniejszości w organach władzy regionalnej i ogólnokrajowej). Podobnie charakteryzowana jest sytuacja na Węgrzech:

„Są oprócz tego jeszcze Wendowie, wzdłuż granicy wegiersko-słoweńskiej. Ich język zbliżony jest do słoweńskiego. Bardzo charakterystyczne dla tych Słowian jest to, że dwa lata temu mieli zaledwie jedną organizację, a dzisiaj mają ich bardzo wiele. Są oni narodowością, która teraz najaktywniej szuka wszelkich możliwości pełnienia swej roli mniejszości narodowej"23.

Rozmaite bodźce, za jakie można uznać dobrowolne/przymusowe, pokojowe/konfliktowe, ewolucyjne/rewolucyjne „uwalnianie” etniczności w różnych krajach, odmiennie konstytuowały świadomość poszczególnych zbiorowości środkowo-wschodnioeuropejskich.

22 D. Silverman, Prowadzenie badań jakościowych, tłum. J. Ostrowska, PWN, Warszawa 2008, s. 32-33.

23 L. Sebok, Mniejszości narodowe na Wegrzech, w: Mniejszości narodowe i religijne w Europie ŚrodkowoWschodniej w świetle statystyk XIX i XX wieku, red. J. Skarbek, Z. Sułowski, IEŚW, Lublin 1995, s. 177. 
Refleksje teoretyczne na temat wielokulturowości rozpatrywanej na poziomie politycznym odsyłają do takich pojęć, jak: wielokulturowość oficjalna, polityka uznania różnicy ${ }^{24}$ czy multikulturalizm. Wszystkie wymienione zakładają istnienie pewnych regulacji polityczno-prawnych określających funkcjonowanie mniejszości w ramach grupy dominującej. Należy założyć, iż tam, gdzie mamy do czynienia z wielokulturowością (a dokładnie: wielokulturowością jako „realnym zróżnicowaniem”), tam powinien zastać wprowadzony multikulturalizm (wielokulturowość polityczna), jest on bowiem "normatywną odpowiedzią na wielokulturowość" 25 . W jej ramach zakłada się zatem stworzenie warunków do zakrojonego na szeroką skalę uczestnictwa mniejszości w życiu społecznym, politycznym i gospodarczym ${ }^{26}$. Wiąże się to z przekonaniem znacznej części społeczeństwa do stanowiska, iż wielokulturowość jest społecznie funkcjonalna, stworzeniem instytucji dbających o wspótistnienie w ramach różnorodności oraz wprowadzeniem idei wielokulturowości do określonego projektu politycznego ${ }^{27}$. Wydaje się zatem, że na tym poziomie zasadnym jest posługiwać się pojęciem multikulturalizmu dla odróżnienia polityki wielokulturowości od wielokulturowości jako empirycznie dostrzeganego zróżnicowania czy świadomości społecznej (niekiedy łączonej bezpośrednio z wielością kultur) ${ }^{28}$.

Badanie wyróżnionego przez nas politycznego poziomu wielokulturowości (multikulturalizmu) wymaga nowej strukturalizacji problematyki badawczej. W tym wymiarze interesujące jest ustalenie, jak oficjalnie kreowana, realizowana i postrzegana jest polityka uznawania różnorodności. Stawiane pytania badawcze mogą dotyczyć:

1) kształtu ideologii wielokulturowości,

2) dominującego systemu aksjonormatywnego i miejsca w nim akceptacji dla zróżnicowania kulturowego,

3) pozycji wielokulturowości w hierarchii problemów społecznych,

4) zakresu swobód i przywilejów instytucjonalno-politycznych dla mniejszości,

5) realizacji praw mniejszości (na przykład w zakresie polityki medialnej),

6) istnienia i kształtu edukacji wielokulturowej.

Osiągnięcie tak określonych celów możliwe jest przy zastosowaniu analizy treści i analizy dyskursu publicznego. Celem pierwszej procedury badawczej jest identyfikacja i od-

24 Postulat „uznania różnicy” zakłada stworzenie warunków umożliwiających każdej jednostce zdefiniowanie własnej tożsamości dzięki odnalezieniu grupy (grup), z którą czuje się najbardziej spokrewniona, a każdej takiej grupie - sformułowanie "autentycznej” tożsamości wynikającej z samookreślenia a nie narzucenia. W.J. Burszta, op. cit., s. 55.

25 M. Buchowski, Antropologiczne kłopoty z multikulturalizmem, w: Czy klęska wielokulturowości, red. H. Mamzer, Poznań 2008, s. 37. Dorota Kołodziejczyk pisze, iż wielokulturowość czyni politykę multikulturalizmu konieczną: Między asymilacją a niepamięcią - czy w multikulturalizmie jest miejsce dla różnicy, "Sprawy Narodowościowe" 1999, z. 14-15, s. 61.

26 E. Możejko, Wielka szansa czy iluzja: wielokulturowość w dobie ponowoczesności, [w:] Dylematy wielokulturowości, red. W. Kalaga, Kraków 2004, s. 149. Autor wymienia cztery poziomy wielokulturowości w jej oficjalnym wydaniu: po pierwsze, odnosi się do daleko posuniętej heterogeniczności etnicznej i kulturowej; po drugie, oznacza ideał równości i poszanowania grup konstytuujących ową heterogeniczność; po trzecie, obejmuje całą sferę badań w zakresie kulturoznawstwa, historii, literaturoznawstwa, etnologii itd., co pociąga za sobą konieczność rewizji szkolnych programów nauczania po czwarte, służy jako nazwa na oznaczenie zasad polityki wewnętrznej łączącej w sobie także, oprócz kwestii powyżej wymienionych, zasadę pełnego równouprawnienia obywateli niezależnie od ich pochodzenia, rasy, płci czy religii. Ibidem, s. 148.

27 J. Mucha, op. cit., s. 52

28 Z kolei Andrzej Sadowski posługuje się pojęciem wielokulturowości, rezerwując ją tylko dla stanu społecznego, w którym mamy do czynienia z instytucjonalizacją zróżnicowania kulturowego. Organizacja społeczeństwa wielokulturowego wiąże się z procesem przechodzenia od społeczeństwa zróżnicowanego kulturowo, przez społeczeństwo oparte na pluralizmie kulturowym do społeczeństwa wielokulturowego. A. Sadowski, Dialog w społeczeństwie zróżnicowanym kulturowo, w: Etniczność - o przemianach spoteczeństw narodowych, red. M. Szmeja, Zakład Wydawniczy NOMOS, Kraków 2008, s. 204. 
powiednie uporządkowanie zawartości wybranych dokumentów lub ich fragmentów. Na podstawie analizy zawartych w nich treści wnioskować można o niejęzykowych zjawiskach rzeczywistości społecznej. Ustaliwszy wymiar treści pozostający w kręgu naszych zainteresowań, tworzymy klucz kategorii analitycznych, którym można się posługiwać w analizie adekwatnych aktów prawnych, podręczników szkolnych, statutów organizacji mniejszościowych. Analiza dyskursu nie jest tożsama z analizą treści. Dyskursem możemy określić wszelkie działania komunikacyjne, który poprzez swoją siłę legitymizowania uprawnionych tematów i znaczeń staje się elementem przemocy symbolicznej. Cechą dystynktywną zjawiska jest immanentnie wpisane weń sprzężenie zwrotne, dyskurs bowiem z jednej strony jest społecznie konstruowany, z drugiej na rzeczywistość społeczną wpływa - i w pierwszym, i w drugim przypadku jego struktury winny być analizowane. Danymi w analizie dyskursu mogą stać się stenogramy debat sejmowych, wypowiedzi publiczne elit, zapisy dyskusji internetowych oraz wszelkie treści medialne.

W Europie Środkowo-Wschodniej mulitkulturalizm w rozumieniu politycznego projektu to stosunkowo nowa koncepcja, na różnym etapie wdrażania. Niesie jednak za sobą szereg różnych problemów. Jednym z nich jest z pewnością wykorzystywanie w refleksji badawczej zachodnich koncepcji multikulturalizmu w kontekście odmiennym od tego, w którym zostały stworzone i bez uwzględnienia specyfiki społecznej i historycznej obszarów, do których analizy zostały zaadaptowane ${ }^{29}$. Specyfika ta związana jest między innymi z określonymi „typami wielokulturowości” - wielokulturowością imigracyjną („nowe mniejszości" o imigranckim rodowodzie) oraz wielokulturowością łączoną z historycznym zróżnicowaniem narodowym, etnicznym, regionalnym, językowym - wiązanymi z dominującymi na danym obszarze modelami narodu: „obywatelskiego" i „etno-kulturowego"30. Rodzaj grup mniejszościowych wyznacza też ramy dyskursu politycznego na temat ich praw: w Europie Zachodniej punkt ciężkości spoczywa na mniejszościach imigracyjnych, a w Środkowo-Wschodniej - na mniejszościach autochtonicznych ${ }^{31}$. Wielokulturowość środkowo-wschodnioeuropejską uzupełnić należy dwoma jedynie zasygnalizowanymi wątkami. Pierwszy dotyczy specyfiki państw postsocjalistycznych, w których wielokulturowość miała charakter "ukryty” i funkcjonowała jedynie w świadomości ludzi, bez oparcia w instytucjach publicznych ${ }^{32}$. Drugi z kolei wiąże się ze zmianami ustrojowymi i poszerzeniem granic Unii Europejskiej, w konsekwencji czego również w krajach Europy Środkowo-Wschodniej obserwujemy wzmożony napływ imigrantów, a to z kolei powoduje wzrost znaczenia wielokulturowości o odmiennym niż dotychczas charakterze ${ }^{33}$ (mimo innego pochodzenia imigrantów).

Jest szczególnie frapujące, jak w naszej części kontynentu nowe i stare państwa radzą sobie politycznie z sytuacją zróżnicowania własnych społeczeństw. Można się przyjrzeć obowiązującym aktom prawnym regulującym kwestie mniejszości, czasowi ich procedowania, definiowania i klasyfikowania mniejszości. Egzemplifikując powyższe, można podać przykład Czechów:

29 M. Buchowski, op. cit., s. 38

30 W.J. Burszta, op. cit., s. 53 oraz S. Łodziński, Polskie regulacje prawne dotyczące mniejszości narodowych i cudzoziemców na tle zasad polityki wielokulturowości, "Sprawy Narodowościowe” 1999, z. 14-15, s. 82-83.

31 C. Obracht-Prondzyński, Mniejszości w nowej Europie - między partycypacją a separacją, w: Pogranicza i multikulturalizm w warunkach Unii Europejskiej. Implikacje dla wschodniego pogranicza Polski, red. K. Krzyszofek, A. Sadowski, Wydawnictwo Uniwersytetu w Białymstoku, Białystok 2004, s. 166-167.

32 S. Łodziński, op. cit., s. 84

33 K. Janicka, M. Bojanowski, Stosunek do imigrantów i polityki imigracyjnej w Polsce: specyfika postaw oraz ich uwarunkowania, „Kultura i Społeczeństwo” 2008, nr 2, s. 111. 
„W raporcie z 1999 roku określono liczebność grupy czeskiej na 9770527 (94,8\%), włączając do niej wyróżnionych w 1991 roku Morawian i Ślązaków; także w stosunku do wyników spisu z 1991 roku włączono osoby deklarujące narodowość czechosłowacką do grupy czeskiej"34.

W Polsce duże kontrowersje wzbudza kwestia nieuznawania de iure za mniejszość Ślązaków. Istotne są również zmiany subiektywnych deklaracji i „przepływy” między niektórymi mniejszościami, które mogą mieć polityczny wymiar: w Polsce popularna jest hipoteza o przepływach między mniejszością niemiecką a śląską, na Słowacji wzrost liczebności mniejszości rusińskiej tłumaczony jest zmianą wśród deklarujących wcześniej narodowość ukraińską, na Węgrzech z czasem poszerzano katalog mniejszości rejestrowanych: od siedmiu w spisie z 1990 roku do czternastu w roku 2001, w Bułgarii nie wyróżniono w spisie narodowości pomackiej, w Chorwacji w spisie 2001 roku nie wyróżniono już narodowości jugosłowiańskiej, choć w spisie z 2003 roku w Czarnogórze narodowość ta pojawia się, w Serbii i Czarnogórze część deklarujących się poprzednio jako Muzułmanie obecnie określa się mianem Bośniaków, w Macedonii mniejszość bośniacka została wyróżniona dopiero w spisie z 2002 roku³. Innym sygnalizowanym zagadnieniem jest stanowienie prawa regulującego sytuacje związane z pojawianiem się nowych problemów, na przykład na Litwie, Łotwie i w Estonii:

„Zgodnie z obowiązującymi po 1990 r. regulacjami prawnymi [...] (wprowadzonymi przeważnie aktami niższego rzędu niż ustawa) stali mieszkańcy tych państw nie posiadający obywatelstwa musieli dokonywać rejestracji swego pobytu oraz uzyskać odpowiednie adnotacje w dokumentach osobistych, które oznaczały jednocześnie zezwolenie na pobyt" ${ }^{36}$.

Pozostając w obszarze legislacji, wskazać można kolejny obszar badawczy, jakim jest definiowanie mniejszości, będące jednocześnie polityczną legitymizacją tychże. W Estonii, na przykład, do mniejszości narodowych należą obywatele,

„którzy stale mieszkają w Estonii, różnią się od Estończyków kulturą, językiem i religią oraz pragną zachować własne tradycje i są grupą liczącą ponad 3000 osób"37.

Węgrzy natomiast uchwalili, że

„(...) Mniejszość narodową i etniczną (dalej: mniejszość) stanowi każda zamieszkująca terytorium Republiki Węgierskiej od przynajmniej stu lat grupa narodowa, która wśród mieszkańców państwa znajduje się w liczebnej mniejszości, jej członkami są obywatele Węgier, a od pozostałych mieszkańców różni ją język, kultura i tradycja, a jednocześnie ma świadomość wspólnoty, jest ukierunkowana na wyrażanie i ochronę historycznie powstałych wspólnot" ${ }^{38}$.

W Polsce przyjęto definicję mniejszości narodowej w brzmieniu:

„Mniejszością narodową, w rozumieniu ustawy, jest grupa obywateli polskich, która spełnia łącznie następujące warunki:

1) jest mniej liczebna od pozostałej części ludności Rzeczypospolitej Polskiej;

2) w sposób istotny odróżnia się od pozostałych obywateli językiem, kulturą lub tradycją;

3) dąży do zachowania swojego języka, kultury lub tradycji;

4) ma świadomość własnej historycznej wspólnoty narodowej i jest ukierunkowana na jej wyrażanie i ochronę;

34 G. Janusz, op. cit., s. 116.

Ibidem, s. 197.

36 J. Sozański, Prawa mniejszości narodowych w niepodległej Litwie, Łotwie i Estonii, Wydawnictwo Naukowe SCHOLAR, Warszawa 1998, s. 80.

37 Ustawa z 11 listopada 1993 r. o autonomii kulturalnej mniejszości narodowych, cyt. za: Ibidem, s. 85.

38 S. Pawlak, Ochrona mniejszości narodowych w Europie, Wydawnictwo Naukowe SCHOLAR, Warszawa 2001, s. 153. 
5) jej przodkowie zamieszkiwali obecne terytorium Rzeczypospolitej Polskiej od co najmniej 100 lat;

6) utożsamia się z narodem zorganizowanym we własnym państwie" 39 .

Wiele mówiące wydaje się procedowanie ustaw o mniejszościach narodowych i etnicznych: w Polsce ustawa o mniejszościach była najdłużej procedowaną w najnowszej historii parlamentaryzmu, natomiast na Litwie ustawa z 1989 roku wygasła z początkiem 2010 roku i obecnie trwają prace nad nowym aktem prawnym regulującym prawa mniejszości w Republice Litewskiej.

Ostatni z wyszczególnionych poziomów to propozycja uzupełnienia dotychczas opisanych poziomów wielokulturowości. Wynika ona z obserwacji współczesnej rzeczywistości społecznej, w której nowym, w zasadzie krystalizującym się zjawiskiem w warunkach Europy Środkowo-Wschodniej, jest marketingowe wykorzystywanie wielokulturowości. W marketingowej teorii marki jednym w wyróżnionych składników jest osobowość marki, którą można zdefiniować jako

„zbiór wartości oraz emocji związanych z marką. W takim ujęciu terminu »osobowość marki» pojawiają się określenia typu: wartości marki czy wizerunek emocjonalny, a sfera niefunkcjonalna marki jest opisywana jako wartości i emocje marki lub po prostu wartości dodane" 40 .

Zatem nie powinno dziwić wykorzystywanie w strategiach marketingowych kategorii wielokulturowości. Kraje Europy Środkowo-Wschodniej nie doświadczyły „kryzysu wielokulturowości" (w rozmiarze i kształcie, jaki zjawisko to przybrało w ostatnich latach w Europie Zachodniej), a w dyskusji na ten temat dominowało raczej stanowisko egzotyczności problemów i klęski polityki multikulturalizmu. Mimo to wielokulturowość, również w znaczeniu zróżnicowania etnicznego i religijnego, pozostaje wartością pozytywnie waloryzowaną. Gdyby było inaczej, nie wykorzystywano by jej w budowaniu marki i wizerunku takich podmiotów, jak miasto, region, kraj. Wykorzystywanie w działaniach marketingowych (np. sprzedaż produktu turystycznego „wielokulturowe miasto") i pijarowych (budowanie pozytywnego wizerunku miasta jako otwartego na inność) w praktyce realizowane jest przy użyciu takich „narzędzi”, jak: wystawy sztuki regionalnej, imprezy kulturalne mniejszości, promowanie kuchni etnicznej, szerzenie treści afirmujących różnorodność. Działania te, w mniejszym lub większym stopniu, zasadzają się na obiektywnych przesłankach, z których warto wskazać historycznie zróżnicowane dziedzictwo miasta, regionu, kraju.

Pytania badawcze formułowane na tym poziomie analizy dotyczyć mogą:

1) relacji między oficjalnymi treściami zawierającymi odwołania do wielokulturowości a realnym zróżnicowaniem kulturowym oraz stanem społecznej świadomości,

2) liczby imprez kulturalnych oficjalnie wyposażonych w pierwiastki wielokulturowości,

3) obecności symboliki wielokulturowej w przestrzeni publicznej (interesująca może być tu kwestia różnicy pomiędzy symbolami "naturalnymi” a „wykreowanymi”).

39 http://www.mswia.gov.pl/portal/pl/178/2958/Ustawa_o_mniejszosciach_narodowych_i_etnicznych_oraz_o_ jezyku_regionalnym.html (data pobrania: 30.08.2011).

40 M. Wójcik, Jakościowe badania elementów składowych marki, w: Badania marketingowe. Od teorii do praktyki, red. D. Maison, A. Noga-Bogomilski, GWP, Gdańsk 2007, s. 203. 
Dla zbadania tego wymiaru zjawiska najwłaściwsze wydają się narzędzia oferowane przez analizę treści i analizę dyskursu. Śledzenie zawartości takich dokumentów, jak: strategie miasta, regionów, materiałów promocyjnych, oficjalnych narracji władz i elit, debat publicznych, zawartości mediów, przynieść może wiedzę o sposobie waloryzacji wielokulturowości przez grupę dominującą oraz o tym, co jest podstawą tego rodzaju wielokulturowości (jakie są jej uzasadnienia). Jednocześnie stwarza szansę rozpoznania, czy wielokulturowość marketingowa jest tożsama z wielokulturowością realną i/lub świadomościową.

\section{ZAKOŃCZENIE}

Prezentowany tekst ma być głosem w dyskusji nad stanem i perspektywami współczesnych badań nad wielokulturowością. O potrzebie prowadzenia takich badań oraz swoistym impasie, w jakim się one znalazły, mówi również w swoim programowym artykule pt. "Socjologia wielokulturowości jako nowa subdyscyplina socjologiczna" Andrzej Sadowski ${ }^{41}$. W przedstawionych powyżej rozważaniach podjęto próbę uporządkowania teoretyczno-empirycznego pola wielokulturowości w określonych historycznie i przestrzennie ramach.

Warto podkreślić, że badania poszczególnych poziomów wielokulturowości dotykają różnych wymiarów tego zjawiska. Interesujące, szczególnie w perspektywie empirycznej, mogą okazać się wzajemne relacje pomiędzy nimi, jak i konsekwencje wynikające z możliwości zderzania się wyodrębnionych poziomów. Dla przykładu - badając wielokulturowość w jej wymiarze „świadomościowym”, za priorytet uznać można poznanie swego rodzaju mentalności społecznej, w której jednostki definiują siebie i innych przez pryzmat przynależności do odmiennych kultur, często subiektywnie definiowanych oraz doświadczanych. Dlatego ten rodzaj wielokulturowości nie musi wynikać (a w niektórych przypadkach nie wynika) ze stanu "realnego zróżnicowania”, w którym główną rolę odgrywają obiektywne kryteria wyodrębniania określonych grup kulturowych w ujęciu etnicznym czy narodowym, a to w odniesieniu do nich właśnie określa się nie tylko liczbę mniejszości, ale również liczbę jej członków. Z kolei wielokulturowość „polityczna” w zasadzie wymaga - co wynika z jej założeń - zaistnienia wielokulturowości "realnej”, niemniej jednak związana jest również z wielokulturowością doświadczaną na poziomie społecznej świadomości: może z jednej strony być jej pochodną, z drugiej może ją kreować.

Badanie wielokulturowości w Europie Środkowo-Wschodniej jest szczególnie istotne we współczesnej praktyce badawczej, z jednej strony staje się ona bowiem aksjonormatywnym ideałem, postulowaną, niezbywalną wartością demokracji, z drugiej strony coraz poważniej dyskutuje się płynące z jej strony zagrożenia. Jednak w pewnej mierze odmienny kontekst wielokulturowości - w odniesieniu do państw zachodnioeuropejskich - skłania do poszukiwań zarówno podobieństw, jak i różnic, które pozwoliłyby dookreślić specyfikę wielokulturowości środkowo-wschodnioeuropejskiej, unikając traktowania jej jako „kopii" zachodniej wersji.

41 A. Sadowski, Socjologia wielokulturowości jako nowa subdyscyplina socjologiczna, „Pogranicze. Studia Spoteczne" 2011, t. XVIII. 


\section{Summary}

The article is supposed to be an opinion in the discussion over the state and prospects of modern research on multiculturalism. Taking into account the importance of this phenomenon in the contemporary reality and a variety of approaches both to the way it is defined as well as to its numerous examples, there was made an attempt to delineate multiculturalism as a complex social-cultural phenomenon in Central Eastern European context whose subjects are constituted by all ethnic groups living on this area. This complexity can be seen on four levels of multiculturalism. On the level of 'empirical state of issues' (demographic); social awareness; a political one and a marketing one. Theoretical bases characterizing the specified levels are being consistently connected with methodological proposals within which some guidelines allowing for the specifics of a particular level are presented. These are: a given research/analysis subject and the way of obtaining data - both of a qualitative and quantitative type. The need to carry out-on various levels-the research on multiculturalism in Central Eastern Europe is at the same time connected with a pursuit of the reflection of the specifics of multiculturalism in this part of Europe so that this peculiarity avoids being treated as a 'copy' of the Western European version.

Keywords: multiculturalism, Central Eastern Europe, methodology, definition 